\title{
Acute Hypoxia-Ischemia Results in Hydrogen Peroxide Accumulation in Neonatal But Not Adult Mouse Brain
}

\author{
MICHAEL J. LAFEMINA, R. ANN SHELDON, AND DONNA M. FERRIERO \\ Departments of Neurology [M.J.L., R.A.S., D.M.F.] and Pediatrics [D.M.F.], University of California San Francisco, \\ San Francisco, CA 94143
}

\begin{abstract}
The neonatal brain responds differently to hypoxicischemic injury and may be more vulnerable than the mature brain due to a greater susceptibility to oxidative stress. As a measure of oxidative stress, the immature brain should accumulate more hydrogen peroxide $\left(\mathrm{H}_{2} \mathrm{O}_{2}\right)$ than the mature brain after a similar hypoxicischemic insult. To test this hypothesis, $\mathrm{H}_{2} \mathrm{O}_{2}$ accumulation was measured in postnatal day 7 (P7, neonatal) and P42 (adult) CD1 mouse brain regionally after inducing $\mathrm{HI}$ by carotid ligation followed by systemic hypoxia. $\mathrm{H}_{2} \mathrm{O}_{2}$ accumulation was quantified at 2, 12, 24, and $120 \mathrm{~h}$ after $\mathrm{HI}$ using the aminotriazole (AT)-mediated inhibition of catalase spectrophotometric method. Histologic injury was determined by an established scoring system, and infarction volume was determined. P7 and P42 animals were subjected to different durations of hypoxia to create a similar degree of brain injury. Despite similar injury, significantly less $\mathrm{H}_{2} \mathrm{O}_{2}$ accumulated in $\mathrm{P} 42$ mouse cortex compared with P7 at 2, 12, and $24 \mathrm{~h}$ after $\mathrm{HI}$. In addition, less $\mathrm{H}_{2} \mathrm{O}_{2}$ accumulated in $\mathrm{P} 42$ mouse hippocampus compared with $\mathrm{P} 7$ hippocampus at $2 \mathrm{~h}$. Since immature neurons are more vulnerable to the toxic effects of $\mathrm{H}_{2} \mathrm{O}_{2}$ than mature neurons, this increased accumulation in the immature brain may explain why the neonatal brain may be more devastated, even after a milder degree of acute hypoxicischemic injury. (Pediatr Res 59: 680-683, 2006)
\end{abstract}

$\mathrm{H}^{3}$ ypoxic-ischemic injury to the prenatal and perinatal brain causes devastating brain damage associated with significant morbidity and mortality (1). Neonatal HI often leads to neurologic dysfunction, cerebral palsy, and epilepsy later in life (2).

Previous studies have determined that the response of the immature central nervous system (CNS) to hypoxia-ischemia (HI) differs from that of the mature CNS. In both age groups, the pathogenesis of injury is complex and involves energy depletion, release of excitatory amino acids such as glutamate, activation of $N$-methyl-D-aspartate (NMDA) receptors, accumulation of reactive oxygen species, and initiation of apoptosis (3). However, the extent to which these events promote injury is greatly influenced by age. Primarily, it appears that the neonatal brain may be more vulnerable to $\mathrm{HI}$ than the mature brain because of a greater susceptibility to oxidative

Received September 21, 2005; accepted December 13, 2005.

Correspondence: R. Ann Sheldon, Department of Neurology, P.O. Box 0663, 521 Parnassus Avenue, University of California San Francisco, San Francisco, CA 941430663; e-mail: annshel@itsa.ucsf.edu

This work was supported by the following sources: UCSF School of Medicine Dean's Summer Fellowship, Ralston Scholarship in the Neurosciences, Genentech Foundation Research Fellowship, and National Institute of Health grant NS33997.

DOI: 10.1203/01.pdr.0000214891.35363.6a stress (4). Several cellular and molecular mechanisms may be responsible for this increased susceptibility, including the enzymatic activities of superoxide dismutase (SOD), glutathione peroxidase (GPx), and catalase. After a hypoxic-ischemic insult, these defense mechanisms can become overwhelmed, resulting in accumulation of oxygen free radicals and neuronal death through reactions involving lipid peroxidation, protein oxidation, and DNA damage (5). In addition, the neonatal brain is particularly susceptible to oxidative damage because of its high concentration of unsaturated fatty acids, high rate of oxygen consumption, and availability of redox-active iron (2). Several lines of evidence suggest that the activities and the responses of these enzymes to oxidative stress are age dependent. For instance, GPx levels are low embryonically and neonatally and then gradually increase to reach their maximum levels during adulthood (6). In addition, GPx activity falls dramatically at 2 and $24 \mathrm{~h}$ after $\mathrm{HI}$ in neonatal mice (7). Furthermore, SOD1 overexpression results in marked neuroprotection in adult rats after ischemia-reperfusion (8), whereas SOD1 overexpression in the neonatal animal exacerbates hypoxic-ischemic brain injury (5). A possible explanation for the variable effect of SOD in the brain during different stages of development is that SOD1 transgenic adult mice show an adaptive rise in catalase activity (9), whereas neonatal SOD1 transgenic brains do not show an adaptive increase in either GPx or catalase (7). The consequent imbalance in antioxidant enzyme activities would allow for greater $\mathrm{H}_{2} \mathrm{O}_{2}$ production after $\mathrm{HI}$ and thus greater injury. In fact, the brains of $\mathrm{P} 7$ mice that overexpress SOD1 have a significantly higher $\mathrm{H}_{2} \mathrm{O}_{2}$ concentration at $24 \mathrm{~h}$ after $\mathrm{HI}$ compared with wild-type $\mathrm{P} 7$ mice (7). $\mathrm{H}_{2} \mathrm{O}_{2}$ has been shown to cause apoptosis in cultured oligodendroglia (10) and neurons (11) and is more toxic to immature neurons in vitro than to mature cells (12).

Therefore, the hypothesis is that given a similar acute ischemic injury, immature brain will accumulate more $\mathrm{H}_{2} \mathrm{O}_{2}$ than the mature brain in regions of damage. To address this hypothesis, conditions were determined that would result in a

Abbreviations: AT, aminotriazole; GPx, glutathione peroxidase; $\mathbf{H}_{2} \mathbf{O}_{2}$, hydrogen peroxide; HI, hypoxia-ischemia; OL, oligodendrocyte; P, postnatal day; SOD, superoxide dismutase 
similar degree of acute injury at $\mathrm{P} 7$ and $\mathrm{P} 42$ in the mouse brain and relative $\mathrm{H}_{2} \mathrm{O}_{2}$ accumulation during the evolution of this hypoxic-ischemic injury in the cortex and hippocampus was ascertained.

\section{METHODS}

Animals. All experiments were approved by the Institutional Animal Care and Use Committee at the University of California San Francisco and carried out with the highest standards of care and housing, according to the National Institutes of Health Guide for the Care and Use of Laboratory Animals. A total of 195 CD1 male mice were used for these experiments. Only male mice were used for these experiments as previous data illustrate that female adult mice are more resistant to damage (13). The CD1 strain was chosen because previous research suggests these mice are particularly susceptible to brain damage in the HI model (14).

Hypoxic-ischemic injury. HI was induced with an adaptation of the Rice-Vannucci procedure $(5,15)$. On P7 or P42, mice were anesthetized with $2.5 \%$ halothane, $30 \%$ nitrous oxide, balance oxygen. The right common carotid artery was exposed and permanently ligated by electrical coagulation. After a 2-h recovery period, P7 and P42 mice were placed in a hypoxic chamber $\left(8 \%\right.$ oxygen/balance nitrogen) in a $37^{\circ} \mathrm{C}$ water bath for 30 or $40 \mathrm{~min}$, respectively. It has been shown that mortality is high in adult mice after HI (13), which we found to be true as well, so we performed preliminary experiments that demonstrated that durations of 30 min of hypoxia in P7 mice and 40 min of hypoxia in P42 mice would produce a similar degree of injury between the two age groups, while minimizing mortality.

Histology and volume of infarction. For examination of the degree of injury after HI, animals were anesthetized with a lethal dose of pentobarbital at either $24 \mathrm{~h}$ or $5 \mathrm{~d}$ after HI. Brains were removed after perfusion fixation with $4 \%$ paraformaldehyde in $0.1 \mathrm{~mol} / \mathrm{L}$ phosphate buffer $(\mathrm{pH}$ 7.4). Fiftymicrometer sections were cut on a vibrating microtome, and sections were stained with cresyl violet or iron stain for injury scoring. Analysis was performed in a blinded fashion on P7 $(n=6)$ and P42 $(n=6)$ brain sections at $5 \mathrm{~d}$ post-HI. Scoring was based on a previously described method in which brains are scored from 0 to 24 , with $0=$ no histologic injury and $24=$ large cystic infarction (14).

The percentage of volume of brain infarction was determined for P7 $(n=$ 6) and P42 $(n=6)$ mouse brains at $5 \mathrm{~d}$ after HI by photographing and measuring the area of surviving hemisphere in consecutive sections with a video image analysis system. Using Neurolucida and Neuroexplorer software (Microbrightfield, Williston, VT), the contralateral and surviving ipsilateral hemispheres of eight coronal sections from each brain were measured at the level of the anterior hippocampus by tracing the image. The hemispheric infarct volume in each brain was calculated as previously described (16).

P7 $(n=5)$ and P42 $(n=5)$ mouse brains were also prepared histologically at $24 \mathrm{~h}$ after $\mathrm{HI}$ to show the extent of injury at this early stage in the progression of injury.

Catalase assay and AT treatment. $\mathrm{H}_{2} \mathrm{O}_{2}$ can be converted to $\mathrm{H}_{2} \mathrm{O}$ and $\mathrm{O}_{2}$ by catalase or GPx. Catalase binds to $\mathrm{H}_{2} \mathrm{O}_{2}$ in the process of decomposing it. AT selectively and irreversibly inhibits catalase that is bound to $\mathrm{H}_{2} \mathrm{O}_{2}(17,18)$. Thus, inhibition of catalase activity by AT is directly proportional to the $\mathrm{H}_{2} \mathrm{O}_{2}$ concentration at the time of AT exposure (19). This is an indirect measurement, and we therefore refer to results as $\mathrm{H}_{2} \mathrm{O}_{2}$ accumulation rather than concentration. To assess the accumulation of $\mathrm{H}_{2} \mathrm{O}_{2}$ after $\mathrm{HI}, \mathrm{P} 7(n=64)$ and $\mathrm{P} 42(n=60)$ mice were killed at 2,12 , and $24 \mathrm{~h}$ and $5 \mathrm{~d}$ after $\mathrm{HI}$ and the cortices and hippocampi were dissected free on ice. Brains were flash frozen and stored at $-80^{\circ} \mathrm{C}$. Two hours before sacrifice, mice were injected intraperitoneally with AT ( $200 \mathrm{mg} / \mathrm{kg}$ in normal saline; $n=60)$ or an equivalent volume of vehicle $(n=64)$. This time point was chosen for P42 mice based on a time curve of inhibition of catalase after injection of AT demonstrating $50 \%$ inhibition at $2 \mathrm{~h}$ (Fig. 1). This value agrees with previously published results for P7 CD1 mice that also showed $50 \%$ inhibition of catalase $2 \mathrm{~h}$ after injection of AT (7), although absolute values differed.

Catalase activity was then measured in the brains of these mice as described previously with slight modification $(7,9,19)$. Activity was determined in duplicate samples by kinetic colorimetric assay following the decrease in absorbance of a known concentration of $\mathrm{H}_{2} \mathrm{O}_{2}$ at $240 \mathrm{~nm}$ over $1 \mathrm{~min}$ and expressed as units per milligram of protein, with 1 unit defined as $1 \mu \mathrm{mol}$ of $\mathrm{H}_{2} \mathrm{O}_{2}$ reduced per minute. All values were normalized to an internal control that consisted of several homogenized cortices and hippocampi. Data are expressed as the percentage of inhibition of catalase activity by AT.

Tissue levels of AT in P7 $(n=12)$ and P42 $(n=12)$ were assayed by the colorimetric method of Green and Feinstein (20) using a protocol previously described in detail (19). In brief, AT is first diazotized by sodium nitrate and

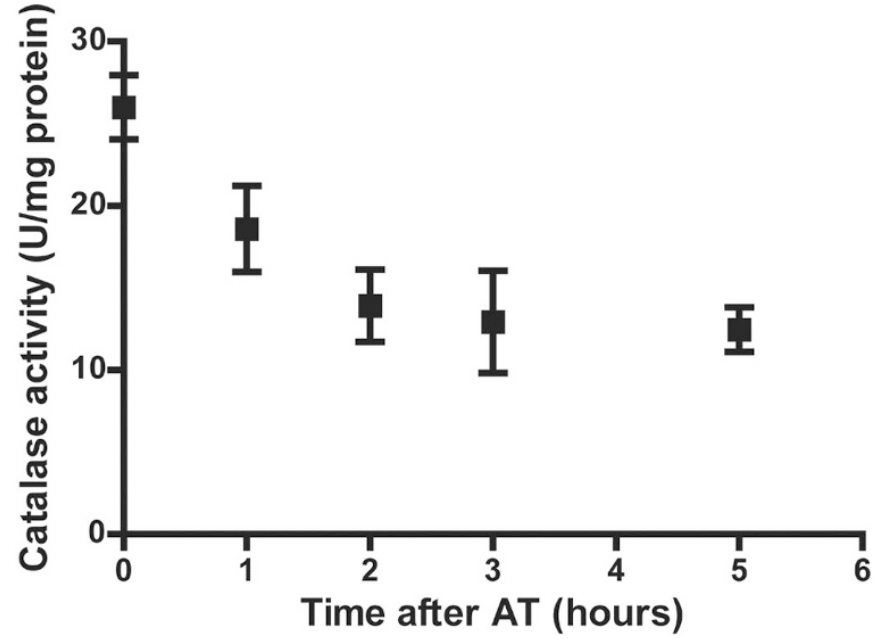

Figure 1. Time curve for inhibition of catalase by AT. P42 CD1 mice were injected intraperitoneally with AT (200 mg/kg of body weight) and killed at $1,2,3$, and $5 \mathrm{~h}$ after injection ( $n=10,8,14$, and 14 , respectively). Control mice were injected with an equivalent volume of normal saline $(n=6)$. Catalase activity in the cortex and hippocampus is expressed in units per milligram of protein, where 1 unit equals $1 \mu \mathrm{mol}$ of $\mathrm{H}_{2} \mathrm{O}_{2}$ reduced per minute. Results are expressed as mean $\pm \mathrm{SD}, p<0.0001$ at all time points, compared with saline. Data from the cortex and hippocampus are combined because they were not significantly different.

then coupled to chromotropic acid to form a colored derivative, the absorbance of which is read at $525 \mathrm{~nm}$. All samples were run as a single assay. Results were expressed as micrograms of AT per milligram of protein.

Statistical analysis. The volume of infarction and histologic damage score were analyzed by the Mann-Whitney test. The catalase activity time curve was analyzed with a one-way analysis of variance (ANOVA) comparing each time point to uninhibited catalase activity in naïve (no HI) brain followed by post hoc Dunnett's test. AT concentration and percentage inhibition of catalase after HI in hippocampus and cortex were analyzed with two-way ANOVA followed by Bonferroni post hoc test. Significance was established at $p<0.05$. All statistical analyses were performed with Prism Version 4 software (Graphpad Software, San Diego, CA).

\section{RESULTS}

Brain injury, histologic damage, and volume of infarction. Exposing P7 mice to $30 \mathrm{~min}$ of hypoxia and P42 mice to $40 \mathrm{~min}$ of hypoxia resulted in similar injury at $5 \mathrm{~d}$ post-HI as measured by histologic damage score and volume of infarction. By $24 \mathrm{~h}$ after $\mathrm{HI}$, severe unilateral injury was obvious in both P7 and P42 mouse brains. Neuronal loss and disorganization of the infarcted region were evident to a similar extent. At $5 \mathrm{~d}$ after $\mathrm{HI}, \mathrm{P} 7$ damage had progressed to cystic infarction, with considerable tissue loss. At $5 \mathrm{~d}$ after HI, P42 mice had a similar degree of injury. However, the neonatal brain had cavitated, whereas the adult brain had scarred with no remaining neurons in the core and penumbral regions.

Overall, P7 and P42 mice had similar injuries as measured by histologic scoring of damage [Fig. 2A: P7 median injury score $=15.5$ (range, 5-24) versus $\mathrm{P} 42$ median injury score $=$ 19 (range, 1-24), $p=0.9372$ ] and percentage of volume of infarction (Fig. 2 B: $\mathrm{P} 7$ mean $\pm \mathrm{SD}=42.0 \pm 17.4$ versus $\mathrm{P} 42$ mean $\pm \mathrm{SD}=48.7 \pm 12.2, p=0.9372$ ).

$\mathrm{H}_{2} \mathrm{O}_{2}$ production. The AT method to identify $\mathrm{H}_{2} \mathrm{O}_{2}$ accumulation in vivo was used (7). It was first demonstrated that there was no significant difference in brain tissue levels of AT measured at 2, 12, and $24 \mathrm{~h}$ and $5 \mathrm{~d}$ after HI. Average 


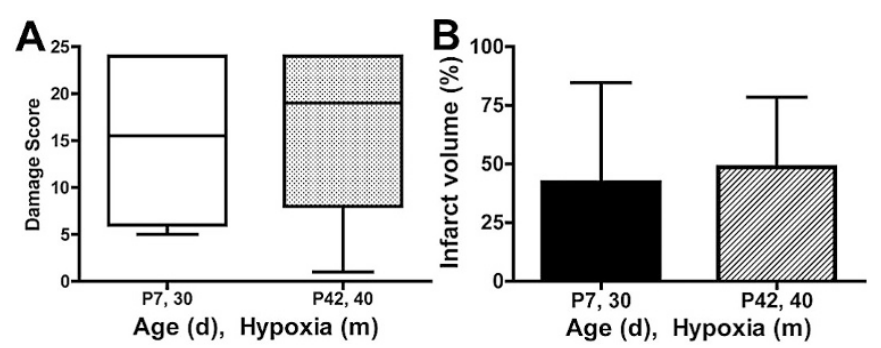

Figure 2. Brain injury after $\mathrm{HI}$ in the neonatal and adult mouse brain. (A) Histologic injury score $5 \mathrm{~d}$ after HI. The horizontal line represents the median score. P7 median injury score $=15.5$ (range, $5-24 ; n=6$ ) $v s$ P42 median injury score $=19$ (range, $1-24 ; n=6$ ), $p=0.9372$. (B) The percentage of volume of infarction $5 \mathrm{~d}$ after $\mathrm{HI}(\mathrm{P} 7$ mean $\pm \mathrm{SD}=42.0 \pm 17.4$ vs $\mathrm{P} 42$ mean $\pm \mathrm{SD}=48.7 \pm 12.2, p=0.9372$ ).

concentrations were $11.5 \pm 1.0 \mu \mathrm{g} / \mathrm{mg}$ protein (P7) versus $13 \pm 4 \mu \mathrm{g} / \mathrm{mg}$ protein (P42). At all other time points, the concentrations were $15.0 \pm 2.0$ in both groups. Therefore, the time points chosen for measurement of $\mathrm{H}_{2} \mathrm{O}_{2}$, by using the AT inhibition of catalase assay, were justified based on the appearance and the half-life of the drug in the brain (Fig. 1).

Less $\mathrm{H}_{2} \mathrm{O}_{2}$ accumulated in $\mathrm{P} 42$ mouse cortex at 2, 12, and $24 \mathrm{~h}$ after HI compared with P7 mouse cortex (Fig. 3A, $p<$ 0.001 at all time points). In addition, less $\mathrm{H}_{2} \mathrm{O}_{2}$ accumulated in the P42 mouse hippocampus at $2 \mathrm{~h}(p<0.001), 12 \mathrm{~h}(p<$ $0.01)$, and $24 \mathrm{~h}(p<0.001)$ after HI compared with $\mathrm{P} 7$ hippocampus (Fig. $3 B$ ) $\mathrm{H}_{2} \mathrm{O}_{2}$ accumulation in contralateral to ligation, nonischemic hemispheres in both $\mathrm{P} 7$ and $\mathrm{P} 42$ mice was not significantly different from the accumulation found in uninjured brains (data not shown); in addition, $\mathrm{H}_{2} \mathrm{O}_{2}$ accumulation was similar between $\mathrm{P} 7$ and $\mathrm{P} 42$ mouse in naïve brain in both the cortex and hippocampus.

While there was a trend toward greater mortality in the adult mice after HI compared with the neonatal mice, it was not significant $(\mathrm{P} 7$ mortality $=10 \%$ versus $\mathrm{P} 42$ mortality $=$ $33 \% ; p=0.06)$.

\section{DISCUSSION}

The major finding in this study is that, given a similar ischemic injury, the adult mouse brain accumulates less $\mathrm{H}_{2} \mathrm{O}_{2}$
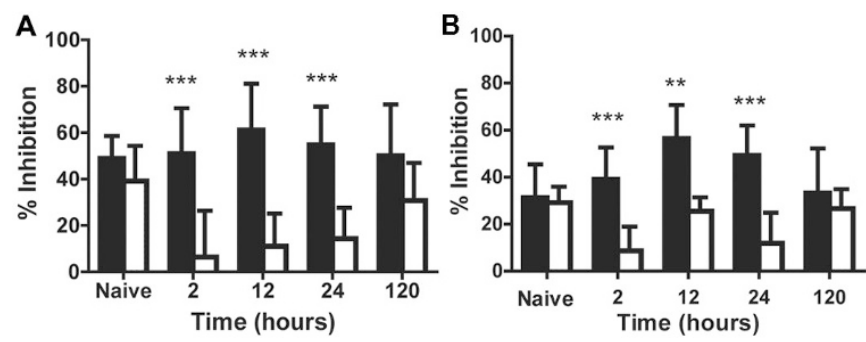

Figure 3. $\mathrm{H}_{2} \mathrm{O}_{2}$ accumulation, as measured indirectly by the AT inhibition of catalase activity, in P7 (ם;n=64) and P42 $(\square ; n=60)$ mouse brain. (A) Less $\mathrm{H}_{2} \mathrm{O}_{2}$ accumulated in ipsilateral to ligation $\mathrm{P} 42$ cortex at 2, 12, and $24 \mathrm{~h}$ ( $p<0.001$ at all time points) after HI compared with P7 cortex. There is no difference between the naïve and postischemic states at P7. P42, however, has less $\mathrm{H}_{2} \mathrm{O}_{2}$ accumulation at $2 \mathrm{~h}$ after $\mathrm{HI}$ than naïve. (B) Less $\mathrm{H}_{2} \mathrm{O}_{2}$ accumulated in ipsilateral to ligation $\mathrm{P} 42$ hippocampus at $2 \mathrm{~h}(p<0.001)$, $12 \mathrm{~h}(p<0.01)$, and $24 \mathrm{~h}(p<0.001)$ after HI compared with P7 hippocampus. Data are expressed as the percentage of inhibition of catalase activity by AT. Error bars are \pm SD. than the neonatal brain in damaged regions. The importance of this finding is that $\mathrm{H}_{2} \mathrm{O}_{2}$ may be the critical mediator in determining whether downstream signaling will favor cell death or repair. While it is well-known that $\mathrm{H}_{2} \mathrm{O}_{2}$ is toxic to developing neurons and oligodendrocytes (OLs) (10-12), recent studies suggest that $\mathrm{H}_{2} \mathrm{O}_{2}$ induces preconditioning neuronal protection in vitro and in vivo $(21,22)$. Therefore, critical control of these levels will determine the ultimate evolution of brain damage. The accumulation of $\mathrm{H}_{2} \mathrm{O}_{2}$ in the first $24 \mathrm{~h}$ after $\mathrm{HI}$ in the neonatal mouse brain versus similar brain regions in the adult can be explained by an imbalance between $\mathrm{H}_{2} \mathrm{O}_{2}$ production and consumption and better consumption of $\mathrm{H}_{2} \mathrm{O}_{2}$ after injury in the adult mouse. A tenuous balance exists between the $\mathrm{H}_{2} \mathrm{O}_{2}$-producing and -consuming enzymes in the uninjured state, and the balance is disturbed when an injury occurs. For example, an increase in GPx activity might be expected after an ischemic insult as a compensatory mechanism in response to accumulation of $\mathrm{H}_{2} \mathrm{O}_{2}$, and this has been shown to be the case in adult models of stroke (23). However, we did not find an increase in GPx activity in P7 mice after hypoxic-ischemic injury in a recent study (24). It is possible that the decrease in inhibition in the mature mice does not reflect a decrease in the rate of $\mathrm{H}_{2} \mathrm{O}_{2}$ production, but rather is due to diversion of $\mathrm{H}_{2} \mathrm{O}_{2}$ away from catalase to GPx or other scavenging enzymes. This is supported further by the fact that catalase activity does not change after ischemia in the neonatal brain (7).

Support of our hypothesis that the balance of scavenging enzymes is critical in an age-dependent manner is documented in a study of immature rat OLs found to be more sensitive to $\mathrm{H}_{2} \mathrm{O}_{2}$ than mature rat OLs. The mature OLs were able to degrade $\mathrm{H}_{2} \mathrm{O}_{2}$ faster than developing OLs, and this increased degradation was likely secondary to the 2- to 3 -fold increase in GPx expression and activity observed in these cells. Inhibition of GPx by mercaptosuccinate made the mature OLs vulnerable to $\mathrm{H}_{2} \mathrm{O}_{2}$ (25). Additional support is provided by the finding that immature transgenic mice that overexpress GPx have less injury after HI than wild-type littermates (24). Also, neurons cultured from mice that overexpress GPx, when exposed to $\mathrm{H}_{2} \mathrm{O}_{2}$, are resistant to injury (26).

In conclusion, this study shows that given a similar degree of initial injury, the neonatal mouse brain accumulates more $\mathrm{H}_{2} \mathrm{O}_{2}$ than the adult mouse brain in regions of damage. It is currently unclear whether this increased accumulation of $\mathrm{H}_{2} \mathrm{O}_{2}$ is responsible for injury propagation or whether $\mathrm{H}_{2} \mathrm{O}_{2}$ is the critical mediator of downstream signaling determining whether the brain is capable of repair or is destined for further cell death. Further studies on the neuromodulatory role of $\mathrm{H}_{2} \mathrm{O}_{2}$ are needed to fully understand its role in hypoxicischemic brain injury.

Acknowledgments. The authors thank Stephan Christen, Ph.D., for his valuable comments on the manuscript.

\section{REFERENCES}

1. Vannucci RC 1990 Experimental biology of cerebral hypoxia-ischemia: relation to perinatal brain damage. Pediatr Res 27:317-326

2. Ferriero DM 2004 Neonatal brain injury. N Engl J Med 351:1985-1995 
3. Vexler ZS, Ferriero DM 2001 Molecular and biochemical mechanisms of perinatal brain injury. Semin Neonatal 6:99-108

4. Ferriero DM 2001 Oxidant mechanisms in neonatal hypoxia-ischemia. Dev Neurosci 23:198-202

5. Ditelberg JS, Sheldon RA, Epstein CJ, Ferriero DM 1996 Brain injury after perinatal hypoxia-ischemia is exacerbated in copper/zinc superoxide dismutase transgenic mice. Pediatr Res 39:204-208

6. Aspberg A, Tottmar O 1992 Development of antioxidant enzymes in rat brain and in reaggregation culture of fetal brain cells. Brain Res Dev Brain Res 66:55-58

7. Fullerton HJ, Ditelberg JS, Chen SF, Sarco DP, Chan PH, Epstein CJ, Ferriero DM 1998 Copper/zinc superoxide dismutase transgenic brain accumulates hydrogen peroxide after perinatal hypoxia ischemia. Ann Neurol 44:357-364

8. Chan PH, Kawase M, Murakami K, Chen SF, Li Y, Calagui B, Reola L, Carlson E, Epstein CJ 1998 Overexpression of SOD1 in transgenic rats protects vulnerable neurons against ischemic damage after global cerebral ischemia and reperfusion. J Neurosci 18:8292-8299

9. Przedborski S, Jackson-Lewis V, Kostic V, Carlson E, Epstein CJ, Cadet JL 1992 Superoxide dismutase, catalase, and glutathione peroxidase activities in copper/zincsuperoxide dismutase transgenic mice. J Neurochem 58:1760-1767

10. Richter-Landsberg C, Vollgraf U 1998 Mode of cell injury and death after hydrogen peroxide exposure in cultured oligodendroglia cells. Exp Cell Res 244:218-229

11. Whittemore ER, Loo DT, Watt JA, Cotman CW 1995 A detailed analysis of hydrogen peroxide-induced cell death in primary neuronal culture. Neuroscience 67:921-932

12. Mischel RE, Kim YS, Sheldon RA, Ferriero DM 1997 Hydrogen peroxide is selectively toxic to immature murine neurons in vitro. Neurosci Lett 231:17-20

13. Vannucci SJ, Willing LB, Goto S, Alkayed NJ, Brucklacher RM, Wood TL, Towfighi J, Hurn PD, Simpson IA 2001 Experimental stroke in the female diabetic, $d b / d b$, mouse. J Cereb Blood Flow Metab 21:52-60

14. Sheldon RA, Sedik C, Ferriero DM 1998 Strain-related brain injury in neonatal mice subjected to hypoxia-ischemia. Brain Res 810:114-122

15. Rice JE 3rd, Vannucci RC, Brierley JB 1981 The influence of immaturity on hypoxic-ischemia brain damage in the rat. Ann Neurol 9:131-141
16. Swanson RA, Morton MT, Tsao-Wu G, Savalos RA, Davidson C, Sharp FR 1990 A semiautomated method for measuring brain infarct volume. J Cereb Blood Flow Metab 10:290-293

17. Nicholls P 1962 The reaction between aminotriazole and catalase. Biochim Biophys Acta 59:414-420

18. Margoliash E, Novogrodsky A, Schejter A 1960 Irreversible reaction of 3-amino1:2:4-triazole and related inhibitors with the protein of catalase. Biochem J 74:339348

19. Sinet PM, Heikkila RE, Cohen G 1980 Hydrogen peroxide production by rat brain in vivo. J Neurochem 34:1421-1428

20. Green FO, Feinstein RN 1957 Quantitative estimation of 3-amino-1,2,4-triazole Anal Chem 29:1658-1660

21. Furuichi T, Liu W, Shi H, Miyake M, Liu KJ 2005 Generation of hydrogen peroxide during brief oxygen-glucose deprivation induces preconditioning neuronal protection in primary cultured neurons. J Neurosci Res 79:816-824

22. Puisieux F, Deplanque D, Bulckaen H, Maboudou P, Gele P, Lhermitte M, Lebuffe $\mathrm{G}$, Bordet R 2004 Brain ischemic preconditioning is abolished by antioxidant drugs but does not up-regulate superoxide dismutase and glutathione peroxidase. Brain Res 1027:30-37

23. Guegan C, Ceballos-Picot I, Nicole A, Kato H, Onteniente B, Sola B 1998 Recruitment of several neuroprotective pathways after permanent focal ischemia in mice. Exp Neurol 154:371-380

24. Sheldon RA, Jiang X, Francisco C, Christen S, Vexler ZS, Tauber MG, Ferriero DM 2004 Manipulation of antioxidant pathways in neonatal murine brain. Pediatr Res $56: 656-662$

25. Baud O, Greene AE, Li J, Wang H, Volpe JJ, Rosenberg PA 2004 Glutathione peroxidase-catalase cooperativity is required for resistance to hydrogen peroxide by mature rat oligodendrocytes. J Neurosci 24:1531-1540

26. McLean CW, Mirochnitchenko O, Claus CP, Noble-Haeusselein LJ, Ferriero DM 2005 Overexpression of glutathione peroxidase protects immature murine neurons from oxidative stress. Dev Neurosci 27:169-175 